\title{
Impacts of Climate Change and Human Activities on Streamflow in the upper basin of the Yongding River, North China
}

\author{
Liqiang Deng ${ }^{1}$, Ying Guo ${ }^{1}$, Yongqing $\mathrm{Qi}^{1}$, and Yanjun Shen ${ }^{1}$ \\ ${ }^{1}$ Institute of Genetics and Developmental Biology Center for Agricultural Resources \\ Research
}

September 22, 2020

\begin{abstract}
Quantitative assessment of the effects of climate change and human activities on runoff is very important for regional sustainable water resources utilization. Determining abrupt changes in runoff could enhance identification of the main driving factors for the sudden changes. In this study, the double mass curves analysis combined with field investigation is used to determine abrupt changes in runoff in two sub-catchments of Upper Yongding River Basin(UYRB), while trend analysis via the traditional Mann-Kendall test for the period 1961-2017 is used to identify the basic trend of precipitation, temperature and potential evapotranspiration(E0). The results suggest an insignificant change in precipitation, a significant increase in temperature and a significant decline in E0 in both sub-catchments. For both of the sub-catchments, abrupt changes in runoff occurred in 1982 and 2003. Both Budyko's curve and double mass curves are used to evaluate the potential impacts of climate variability and human activities on mean annual streamflow. The results showed that, from the 1960s to the 1980s, runoff declined by $20.01 \%$ and $22.28 \%$ for Xiangshuibu and Shixiali, respectively; from the 1980 s to the 2000 s, runoff declined by $68.23 \%$ and $67.77 \%$ respectively. In the variation stage I (1983 2003), human activities contributed $90.6 \%$ and $62.7 \%$ of the mean annual streamflow change in YRB and SRB, respectively. In the variation stage II(2004 2017$)$, human activities contributed $99.5 \%$ and $93.5 \%$ of the change in YRB and SRB, respectively. It is also noted that the first abrupt decline in runoff was actually at the beginning of China's land reform, when the land reform motivated farmers to productively manage their reallocated lands, agricultural water consumption therefore increased. The second abrupt change point occurred in 2003, when "Capital water resources planning" implemented including water conservation projects and irrigation district construction. In general, human activities, including soil and water conservation projects and water consumption, are found to be the dominant factors responsible for the significant decline in the annual streamflow in the UYRB over the last six decades.
\end{abstract}

\section{Impacts of Climate Change and Human Activities on Streamflow in the upper basin of the Yongding River, North China}

Liqiang Deng, Ying Guo*, Yongqing Qi, Yanjun Shen*

Key Laboratory of Agricultural Water Resources, Hebei Key Laboratory of Agricultural Water-Saving, Center for Agricultural Resources Research, Institute of Genetics and Developmental Biology, Chinese Academy of Sciences, Shijiazhuang 050021, China

\section{*Corresponding author.}

Prof. Yanjun Shen

Lab of hydrology and agricultural water resources,

Center for Agricultural Resources Research,

Chinese Academy of Sciences, 
Shijiazhuang 050022, Hebei province, China

Email: yjshen@sjziam.ac.cn

Dr Ying Guo

Lab of hydrology and agricultural water resources,

Center for Agricultural Resources Research,

Chinese Academy of Sciences,

Shijiazhuang 050022, Hebei province, China

Email: guoy@sjziam.ac.cn

\section{Highlights}

1. This study fitted the "basin-specific $\alpha$ " in Yang River and Sanggan River through the annual observation data.

2. In this paper, we study the impact of climate change and human activities on runoff through Budyko type formula, Fu's equation.

3. This paper update about ten years data compare with previous studies; in addition, this study also obtained a large number of field investigation data, which further confirmed the research results.

Abstract : Quantitative assessment of the effects of climate change and human activities on runoff is very important for regional sustainable water resources utilization. Determining abrupt changes in runoff could enhance identification of the main driving factors for the sudden changes. In this study, the double mass curves analysis combined with field investigation is used to determine abrupt changes in runoff in two subcatchments of Upper Yongding River Basin(UYRB), while trend analysis via the traditional Mann-Kendall test for the period 1961-2017 is used to identify the basic trend of precipitation, temperature and potential evapotranspiration $\left(\mathrm{E}_{0}\right)$. The results suggest an insignificant change in precipitation, a significant increase in temperature and a significant decline in $\mathrm{E}_{0}$ in both sub-catchments. For both of the sub-catchments, abrupt changes in runoff occurred in 1982 and 2003. Both Budyko's curve and double mass curves are used to evaluate the potential impacts of climate variability and human activities on mean annual streamflow. The results showed that, from the 1960s to the 1980s, runoff declined by $20.01 \%$ and $22.28 \%$ for Xiangshuibu and Shixiali, respectively; from the 1980 s to the 2000 s, runoff declined by $68.23 \%$ and $67.77 \%$ respectively. In the variation stage I (1983 2003$)$, human activities contributed $90.6 \%$ and $62.7 \%$ of the mean annual streamflow change in YRB and SRB, respectively. In the variation stage $\mathrm{II}\left(2004^{\sim} 2017\right)$, human activities contributed $99.5 \%$ and $93.5 \%$ of the change in YRB and SRB, respectively. It is also noted that the first abrupt decline in runoff was actually at the beginning of China's land reform, when the land reform motivated farmers to productively manage their reallocated lands, agricultural water consumption therefore increased. The second abrupt change point occurred in 2003, when "Capital water resources planning" implemented including water conservation projects and irrigation district construction. In general, human activities, including soil and water conservation projects and water consumption, are found to be the dominant factors responsible for the significant decline in the annual streamflow in the UYRB over the last six decades.

Keywords : Streamflow; Climate variability; Human activities; Yongding River Basin; Budyko's curve

\section{Introduction}

Climate change and increasing human activities is significantly impacting the runoff on a global scale(Xia, 2002; Arnell, 2004; Huntington, 2006; Emad et al., 2018; Falcone et al., 2018). This has become one of the serious issues of scientific concern especially in semi-arid area (Ren et al, 2002; Wang et al., 2011). The runoff of many rivers in semi-arid area has exhibited a significantly decreasing trend that greatly threatens 
water security (Xia, 2004; Braga et al, 2013). Impact of climate change and human activities on runoff has been widely studied(Huang, 2018; Kenny et al, 2019). Many studies have shown that: in the semi-arid area, with the increase of temperature and the decrease of precipitation, runoff will decrease to a certain extent(Nurtaev, 2015; Wang, 2011).Xu (2012) studied the runoff changes of 296 typical watersheds in China in the past 50 years (1956-2005), and quantitatively evaluated the impact of climate change and underlying surface change. The results show that in the Haihe River Basin, the lower Yellow River Basin, the lower Songhua River Basin and the Liaohe River Basin, the underlying surface change is the main reason for the runoff change, while the runoff change in other basins is mainly affected by climate change.

Climate change affects the land hydrological cycle system through the changes of temperature, precipitation and evaporation, thus affecting the hydrological process (Nurtaev, 2015). The influence of human activities on hydrological process is mainly through land use/cover, soil and water conservation and water conservancy projects (Zhao G, 2014). Therefore, the research on the impact of climate change and human activities on hydrological process is of great scientific significance and application value for water resources planning, management and application under changing environment. How to distinguish the contribution rate of climate change and human activities to runoff change is the core issue in the study of hydrology (Liu et al., 2014; Huang et al., 2018).

In terms of the impact of climate change and human activities on runoff, experts have done a lot of research, and considerable attention has been paid to assessing the impacts of climate variability and human-induced land use changes on water resources (Hang et al., 2011; Ma et al., 2008; Milly et al., 2008; Mu et al., 2007; Tao et al., 2011; Zhai et al., 2010; Zhang et al., 2008; Zhang et al., 2011). Assessments of the impacts of climate change on river streamflow are usually performed using hydrological models or by analyzing the variation of hydro-climatic variables (Yao et al., 2011; Wada Y. et al., 2016). Hydrological models, such as the Variable Infiltration Capacity (VIC) model, the SLURP (Semi-distributed Land Use-based Runoff Processes) model, the Xinanjiang model, the HBV model and the Soil and Water Assessment Tool (SWAT), have been commonly applied to assess the impacts of climate change and human activities such as land use changes on streamflow under various scenarios (Pikounis et al, 2003; Fohrer et al., 2005; Choi et al., 2009; Mahmoud et al., 2015). Although hydrological models have clear physical mechanism, a large number of parameters cannot be obtained from field measurements. Additionally, hydrological modeling requires a large number of input data sets and is often seen as time consuming for model calibration and validation. Due to these limitations, new attempts assess the effect of climate variability and human activities have recently been made. In recent years, both the hydrological sensitivity method and a simple water balance model known as Budyko's curve have been widely applied to separate the effects of climate change and human activities on streamflow (Dooge et al., 1999; Milly and Dunne, 2002; Wang et al., 2013a; Zhang et al., 2008). Several analytical equations have been proposed baesd on the Budyko hypothesis (Yang et al., 2008b). In Budyko's original hypothesis, the Budyko curve was regarded as "universal" for all basins at long-term scale and the default Budyko curve method corresponds to a $\alpha$ value of 2.6 [Donohue et al., 2011]. Later on, "basin-specific" Budyko curves were proposed: each basin has a distinct Budyko-type relationship between precipitation $(\mathrm{P})$, potential evaporation $\left(\mathrm{E}_{0}\right)$, and actual evaportranpiration $\left(\mathrm{E}_{\mathrm{a}}\right)$ at annual scale. Consequently, a simple parameterization for $\alpha$ with information that is readily available will be a good basis for applying Fu's equation and the Budyko framework, which would be applied in this study.

The Yongding River Basin (YRB) has served as the "mother river of Beijing" over the past millennia and continues to play a critical role in the development of Beijing (Jinbo, 2012). However, over the last several decades, progress has been impeded by a continuous water shortage. The UYRB, located northwest of Beijing, is a very important sub-basin of the Hai River Basin (Figure 1) because it is the major source of water for the Guanting Reservoir, supplying water to Beijing. This study is focused on the upper areas of the YRB. With the rapid social and economic development that has occurred over the past several decades, water consumption has increased continuously and, consequently, the inflows to the Guanting Reservoir have continuously decreased. The water scarcity in the study area has become increasingly severe (Wang, 2004; Wang et al, 2010), the increase in the amount of water withdrawal from the river course is the direct cause why observed runoff decreases in the northern part of China (Ren et al, 2002). Xia et al (2014) presents 
the analytical derivation method based on Budyko hypothesis to separate the effects of climate change and human activities in Upper Yongding River Basin (UYRB). Results show that climate change is estimated to account for $10.5-12.6 \%$ of the reduction in annual runoff and human activities contribute to $87.4-89.5 \%$ of the runoff decline, indicating that human activities are the main driving factors for the reduction in runoff. Zeng et al (2013) studied the characteristics of water cycle and its response to climate change in YRB by SWAT model. The results indicate that the water resources in YRB will decrease in the early 21st century and increase in the middle of the 21st century and the water resources crisis will be further intensified. Mo et al (2018) studied the impact of climate change and human activities on the runoff of YRB by elastic coefficient method. The results show that the potential evapotranspiration of the basin presents an upward trend, while the rainfall and runoff show a decreasing trend; the abrupt change point of runoff sequence occurred in 1984, and the runoff change rate caused by climate change is $28 \%$, while that caused by human activities is $72 \%$. However, Zhang's (2013) results show that climate change is the dominant influence factor with a contribution of $65.4 \%$.

In previous studies, many methods were used to determine the change point, and the results would be different due to the different length of time series. In addition, most of the studies focus on the period before 2010 (Xia, 2012; Ding, 2013; Xia, 2014; Mo, 2018). However, the runoff of Yongding River has declined rapidly in recent ten years, especially after the "Capital water resources planning". Thus, it is necessary to do further research on the hydrological law of the basin. In addition to the existing methods, this study also obtained a large number of field survey data, which makes the results more accurate and reliable.

Although a few studies have investigated the variability of streamflow in UYRB in response to climate changes and human activities to support future water resource management. The changing streamflow properties and their connection to natural and anthropogenic impacts in the UYRB have not been extensively analyzed, especially after the "Capital water resources planning" project launched by Chinese government in 2003. Furthermore, the scientific community still disagrees on the main factors affecting the regional water resources in the UYRB. The objectives of this study, therefore, are (1) to assess the spatial and temporal variation of streamflow, climatic variables in the UYRB and (2) to quantify the effects of climate variability and human activities on streamflow there.

\section{Materials and Methods}

\subsection{Study area and data sources}

The Upper Yongding River Basin (UYRB), one river system of Haihe river basin, is located in North China. It includes part of Shanxi, Inner Mongolia and Hebei Province, has a population of [?]9.13 million. In this study, the analyzed sub-catchments together have an area of [?]43000 $\mathrm{km}^{2}$, stretching between longitudes $111^{\circ} 58^{\prime}-116^{\mathrm{deg}} 22^{\prime} \mathrm{E}$ and latitudes $38^{\mathrm{deg}} 50^{\prime}-41^{\mathrm{deg}} 16^{\prime} \mathrm{N}$. The area lies at an elevation of $479-2852 \mathrm{~m}$ above mean sea level (Fig. 1). The predominant climate of study area is continental monsoon climate, belonging to semi-arid area, with cold and dry winters and hot and rainy summers. The annual distribution of runoff is very uneven, about $80 \%$ of which is concentrated in the flood season. The annual average precipitation of the basin is less than $450 \mathrm{~mm}$, about $75 \%$ of which falls in the rainy months of June to September. Average annual temperatures in the catchment are between -1.6 and 12.5. Main land use/land cover types are farmland ([?]42\%), grassland ([?]29\%) and forest ([?]10\%). The forests consist mainly of deciduous broad-leaved forests. Maize is the dominant cultivated crops in the single-crop rotation system in the study area. Rainfall often does not meet crop water demand hence irrigated lands have not only increased, but are increasingly reliant on groundwater pumping and river water diversion project. As irrigation significantly enhances harvests, it has therefore become an indispensable agronomic practice in the region. Hence as the largest water user, agricultural water demand has a significant impact on the scale of water deficit in the region.

Daily meteorological data of 23 stations from CMA (Fig. 1) in and around the UYRB during 1961-2017 
were used, including mean daily temperature, precipitation, mean relative humidity, mean wind speed, and sunshine duration. Daily runoff data were collected for the same period from two hydrological gauge stations situated at the outlets of the sub-catchments. Runoff was monitored in rectangular weirs setup in accordance with ISO (International Standards Organization) standards for open-channel liquid flow measurement. The hydrological gauge stations include the, Xiangshuibu station (for $14,600 \mathrm{~km}^{2}$ area of Yanghe River subcatchment), Shixiali station (for $23300 \mathrm{~km}^{2}$ area of Sanggan River sub-catchment). The daily runoff data constitute direct flow measurements from the respective stations (Table 1). The DEM data with a resolution of $30 \mathrm{~m}$ was from ASTER GDEM.

[Figure 1 here]

[Table 1 here]

\subsection{Methods}

\subsubsection{Trend detection}

This study applies the non-parametric Mann-Kendall test to detect trends in the hydro-climatic time series (Kendall, 1975; Mann, 1945). The method has been commonly used to examine trends in hydrometeorological time series such as streamflow, precipitation and temperature in various regions throughout the world ( $\mathrm{Mu}$ et al., 2007; Novotny and Stefan, 2007). For the given time series $\mathrm{X}\left(\mathrm{x}_{1}, \mathrm{x}_{2}, \ldots, \mathrm{x}_{\mathrm{n}}\right)$, the statistic $\mathrm{S}$ is defined as:

$$
\begin{gathered}
S=\sum_{i=2}^{n} \sum_{j=1}^{i-1} \operatorname{sgn}\left(x_{i}-x_{j}\right) \text { where } \operatorname{sgn}\left(x_{j}-x_{i}\right)=\{ \\
1 \quad x_{j}>x_{i} \\
0 \quad x_{j}=x_{i} \\
-1 \quad x_{j}<x_{i}
\end{gathered}
$$

Mann (1945) and Kendall (1975) addressed that the statistic S is approximately normally distributed. Its variance is calculated as:

$\operatorname{var}(S)=\frac{n(n-1)(2 n+5)}{18}$

The standardized statistic is:

$$
\begin{array}{ll}
Z=\{ & \\
\frac{S-1}{\sqrt{\operatorname{var}(S)}} & S>0 \\
0 & S=0 \\
\frac{S-1}{\sqrt{\operatorname{var}(S)}} & S<0
\end{array}
$$

A positive values of $\mathrm{Z}$ indicates an upward trend, while a negative $\mathrm{Z}$ indicates a downward trend. The null hypothesis of no trend is rejected if $|\mathrm{Z}|>1.96$ at $5 \%$ significance level. The effects of the serial correlation on the MK test were eliminated by using the Trend-Free pre-whitening procedure (Yue and Wang, 2004).According to the calculated autocorrelation coefficients at lag-1 for each annual time series, the hydro-climatic series are time-independent.

\subsubsection{Change point detection}

The method of runoff double cumulative curve and field survey data are used to study the abrupt point. The double mass curve is used to check the consistency of many kinds of hydrometeorological data by plotting the graph. The variables is a fixed ratio. Breaks in the double-mass curve of such variables are caused by changes in the relation between the variables (Searcy and Hardison, 1960). Double mass curve is a simple method, computed as follows.

Let the observed variable values $\mathrm{X}_{\mathrm{i}}$ and $\mathrm{Y}_{\mathrm{j}}$, the cumulative amount calculated: 
$X_{i}^{\prime}=\sum_{j=1}^{i} X_{j}(4)$

$$
Y^{\prime}=\sum_{j=1}^{i} Y_{j}(5)
$$

Where, $\mathrm{X}_{\mathrm{i}}$ represents rainfall, and $\mathrm{Y}_{\mathrm{j}}$ is the runoff. The slope of the curve changes are abrupt changes points. In order to accurately determine the mutation time, we also refer to the field survey data, so that the determination of abrupt change points has a solid practical basis.

\subsubsection{Separating the impact of climate change and human activity on streamflow}

To quantitatively analyze the effects of climate variability and human activities on streamflow, both the water balance based Budyko model (1974) and a double mass curves method were applied to the hydroclimatic series during the two periods identified by the double mass curves combined with field investigation. The water balance in a catchment scale can be quantified as:

$Q=P-E_{a}-S(6)$

Where $\mathrm{P}$ is the precipitation $(\mathrm{mm}), \mathrm{E}_{\mathrm{a}}$ is the actual evapotranspiration $(\mathrm{mm}), \mathrm{Q}$ is the runoff depth $(\mathrm{mm})$, and $\Delta \mathrm{S}$ is the changes in the catchment water storage $(\mathrm{mm})$, which is assumed to be zero over a long period. Following an assumption similar to that made by Budyko (1974), the actual evapotranspiration can be estimated as (Fu, 1981):

$\mathrm{E}_{\mathrm{a}}=\mathrm{PF}()(7)$

$\mathrm{F}(\varphi)=1+\varphi-\left(1+{ }^{\alpha}\right)^{1 / \alpha}(8)$

Where $\varphi=\mathrm{E}_{0} / \mathrm{P}, \mathrm{E}_{0}$ is potential evapotranspiration which was calculated using the Penman-Monteith equation following the procedure outlined in FAO-56 (Allen et al., 1998). $\alpha$ is a model parameter estimated using long-term averaged data. As one form of the Budyko framework, Fu's equation has been widely used to model long-term basin-scale water balance. A detailed description of the values is available in Zhang et al. (2001).

A change in the observed mean annual streamflow $\Delta \mathrm{R}_{\text {total }}$ may result from climate variability $\Delta \mathrm{R}_{\text {clima }}$ or from human activities $\Delta Q_{\text {human }}$

$R_{\text {total }}=R_{\text {clima }}+R_{\text {human }}(9)$

To assess the effects of climate change and human activities, we divided the streamflow records for each catchment that has undergone significant changes in qualities such as land use, dams, afforestation or deforestation into two periods. The first period represents the baseline, when no significant human activities occurred, while the second represents the changed period and is associated with significant human activities. Thus, a change in the average annual streamflow is calculated as:

$Q=Q_{2}-Q_{1}(10)$

Where $Q$ denotes the change in average annual streamflow and $Q_{1}$ and $Q_{2}$ are the average annual streamflow during the baseline period and changed period, respectively.

Precipitation and $\mathrm{E}_{0}$ are the primary climatic variables determining the annual water balance (Zhang et al., 2004). Variations in these variables could lead to changes in the annual streamflow. The relationship between these variables can be estimated as:

$R_{\text {climate }}=\frac{\partial R}{\partial P} P+\frac{\partial R}{\partial \mathrm{ET}_{0}} E_{0}(11)$

where $\Delta \mathrm{P}$ and $\Delta \mathrm{E}_{0}$ are the changes in precipitation and $\mathrm{E}_{0}$, respectively. Consequently, the impact of climate change on streamflow can be quantified as: 
$\frac{\partial R}{\partial P}=P^{\alpha-1}\left(E_{0}^{\alpha}+P^{\alpha}\right)^{\frac{1}{\alpha}-1}(12)$

$\frac{\partial R}{\partial \mathrm{ET}_{0}}=E_{0}^{\alpha-1}\left(E_{0}^{\alpha}+P^{\alpha}\right)^{\frac{1}{\alpha}-1}-1(13)$

In contrast, the runoff double mass curve(DMC) is a statistical method that does not consider the physical hydrological processes that were also established between streamflow and precipitation within the two periods (the changing period and the reference period). The DMC equation between annual streamflow $\left(\mathrm{R}_{\text {ref }}\right)$ and basin-averaged annual precipitation $\left(\mathrm{P}_{\mathrm{ref}}\right)$ in the reference period can be expressed as follows:

$\Sigma R=k \Sigma P+b(14)$

Thus, the impact of human activities and climate change on streamflow can be quantified as:

$\delta_{\mathrm{hi}}=\mathrm{R}_{2 \mathrm{~m}}-\mathrm{R}_{2 \mathrm{c}}(15)$

$\delta_{\mathrm{ci}}=\mathrm{R}_{2 \mathrm{c}}-\mathrm{R}_{1 \mathrm{~m}}(16)$

$\mathrm{Q}_{\mathrm{g}}=\left(\delta_{\mathrm{hi}}\right.$ or $\left.\delta_{\mathrm{ci}}\right) / \mathrm{R}_{\mathrm{d}}(17)$

Where, $\delta_{\mathrm{hi}}$ 和 $\delta_{\mathrm{ci}}$ is runoff depth caused by human activities and climate change respectively $(\mathrm{mm}), \mathrm{Q}_{\mathrm{g}}$ represents the contribution rate(\%) of human activities and climate change to runoff reduction. $\mathrm{R}_{2 \mathrm{~m}}$ represent measured values in variation period, $R_{2 c}$ represent calculated values in variation period, $R_{1 m}$ represent measured values in baseline period.

\section{Results}

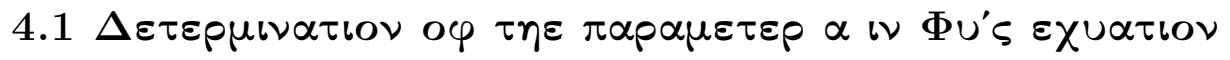

The parameter $\alpha$ represents the integrated effects of catchment attributes (such as climate, vegetation cover, soil properties, and catchment topography) and human activities on $\mathrm{P}$ partitioning (Zhang et al., 2001; Zhou et al., 2015). That is to say, the curve shape parameter $\alpha$ controls how much of the available water will be evaporated given the available energy. $\alpha$ can be estimated by minimizing the difference between water-balance-based $\mathrm{E}_{\mathrm{a}}(\mathrm{P}-\mathrm{Q})$ and simulated $\mathrm{E}_{\mathrm{a}}$ with Fu's equation. The parameter $\alpha$ obtained through this method is also called the "basin-specific $\alpha$ " (Li et al., 2013). In this study, the parameter $\alpha$ was fitted through the annual observation data (Fig 2). A larger $\alpha$ indicates less water yield capacity for a basin given sufficient energy. Obviously, the water yield capacity of Yang River is larger than Sanggan River. For both sub-catchments, all annual dryness indices $\left(\Phi=\mathrm{ET}_{0} / \mathrm{P}\right)$ is greater than one, means that the limiting factor to evapotranspiration is energy supply.

[Figure 2 here]

\subsection{Spatiotemporal variation characteristics of meteorological variables}

Fig.3 shows spatiotemporal variation characteristics in precipitation $(\mathrm{P})$ and potential evapotranspiration $\left(\mathrm{ET}_{0}\right)$, estimated by the M-K test and Kriging interpolation method. Average annual precipitation for the sub-catchments is $319.4-554.1 \mathrm{~mm}$ and precipitation in the UYRB is relatively stable. As shown in Fig 3a, the annual precipitation showed an upward trend at 13 stations and a downward trend at 9 stations, but not significant, with $\mathrm{Z}$ value $0.154 \sim 1.167$ and $-1.074 \sim-0.027$, respectively. Fig 3 a also shows that there is a slight increase in precipitation in the Sanggan River basin (SRB). Comparing with the background topography, we find that the precipitation increases with the elevation. At the same time, we analyzed the trend of temperature, and the results showed that temperature at most stations increased by 0.09-0.52 per decade. These changes in temperature duration are not shown in this work. Fig $3 \mathrm{~b}$ shows that the annual average $\mathrm{E}_{0}$ values ranged from 701.5 to $1111.5 \mathrm{~mm} / \mathrm{yr}$ and the $\mathrm{E}_{0}$ of UYRB has a negative trend at 18 stations, with decreases from $-0.18 \mathrm{~mm} / \mathrm{yr}$ to $-2.04 \mathrm{~mm} / \mathrm{yr}$ over the study period. From the perspective of spatial distribution, the northern part of the study area presents a higher $\mathrm{E}_{0}$ value, while the southern 
part is relatively low. This phenomenon is consistent with the global evaporation paradox, which may be caused by several climatic variables. The measured data witnessed a significant reduction in wind speed, which maybe cause the decline of $\mathrm{E}_{0}$ value. The data of wind are not shown in this work.

[Figure 3 here]

\subsection{Trend analysis of annual streamflow}

In this study, annual streamflows at two stations (Fig. 4) are analyzed to assess the trend in this basin during the period 1961-2017. The linear regression analysis shows significant declines in annual runoff trend for Yang river and Sanggan river (not show in this work). The estimated rates of change are $-0.74,-0.80 \mathrm{~mm} / \mathrm{yr}$ for Shixiali and Xiangshuibu, respectively, from 1961 to 2017. From the 1960s to the 1980s, runoff declined by $20.01 \%$ and $22.28 \%$ for Xiangshuibu and Shixiali, respectively. From the 1980s to the 2000s, runoff declined by $68.23 \%$ and $67.77 \%$. As Fig. 3 shows, the runoff decreased rapidly around 2003, with precipitation had no significant trend. It is worth noting that the runoff of YRB and SRB decrease rapidly after 2003.

[Figure 4 here]

\subsection{Change point analysis of annual streamflow}

The method of double mass curve was applied to examine abrupt changes in annual streamflow at two sub-catchment of the upstream area of the Yongding River Basin (Fig. 5). According to the change of the slope of the curve, the first abrupt changes of these two basins most likely occurred in the early 1980s; this pattern can be largely attributed to the operation of the China's land reform that gave responsibility to farmers to productively manage the reallocated lands. The land reform policy was successful because it motivated farmers to increase agricultural production. Increased agricultural activity then results in increased agricultural water use. The second abrupt changes in annual streamflow occurred intensively between 2000 and 2005, which likely predominantly resulted from the "Capital water resources planning", when including large scale soil and water conservations practices and irrigation district construction. In general, 1978-1985 is the period with abrupt decline in runoff in the study area (Yang, 2009; zhang, 2013). To further prove this claim, we organized a two-week large-scale field survey in the upper Yongding River Basin. We found that it was in 1982 that the household contract responsibility system was implemented and the Capital water resources planning was mainly constructed in 2003. After the first point, the response of runoff to precipitation is continuously weakening. Accordingly, these breakpoints divide the study period for all the catchments into three periods: base period(1961-1982), variation stage I(1983-2003) and variation stage II(2004-2017).

[Figure 5 here]

\subsection{Effects of climate variability and human activities on streamflow}

Changes in streamflow for a given study area are affected by many factors that can be attributed to climate variability and human activity. The percentage change in average annual streamflow attributable to climatic variability and human activity are shown in Table 2. As shown in Table 2: the precipitation decreased by $4.46 \%$ and $6.37 \%$ in YRB and SRB during variation stage I (1983 2003), recpectively, compare to the base period; the precipitation decreased by $1.53 \%$ and $0.71 \%$ in YRB and SRB during variation stage II (2004 2017). In addition, the $\mathrm{E}_{0}$ decreased by $3.71 \%$ and $1.35 \%$ in YRB and SRB during variation stage I ,respectively. The $\mathrm{E}_{0}$ decreased by $1.98 \%$ in YRB and increased by 3.18 in SRB during variation stage II. The descriptions above reflect the climatic variables affecting runoff. the Streamflow at two sub-catchment is decreasing at extremely high rates especially the variation stage II, when the runoff of Yang River decreased by $87 \%$ and Sanggan River by $91 \%$ compare to the base period. Human activities are expected to account for more of this reduction in mean annual streamflow than the effects of climate change; this prediction is true at both sub-catchments. In the variation stage I, human activities contributed $90.6 \%$ and $62.7 \%$ of the 
mean annual streamflow change in YRB and SRB, respectively. In the variation stage II, human activities contributed $99.5 \%$ and $93.5 \%$ of the change in YRB and SRB, respectively, which is more affected by human activities than the first period of variation. In general, the contribution rate of human activities to the runoff of Yang River is higher than Sanggan River.

[Table 2 here]

\section{Discussions}

\subsection{Estimation of climate and anthropogenic contributions by double mass curves}

To further address the impacts of human activity on streamflow, double mass curves (DMCs) were plotted to show the correlation between cumulative annual streamflow and precipitation (Fig. 4). In general, the DMC was expected to be a straight line if streamflow was not influenced by human activities. The curves show the best fit between streamflow and precipitation (Zhang and Lu, 2009). Evident abrupt breakpoints can be identified in the DMCs, suggesting that the variations in hydrological processes were not only influenced by precipitation but also by human activities.

The relationships between runoff and precipitation are well represented by three straight lines with different slopes before and after the times of abrupt change. As shown in Fig. 4, the slopes of the regression lines are lower after the transition years than before for the DMCs, which suggests large reductions in streamflow in periods following the transition years. The DMCs method assessed the relative contributions of precipitation and human activity in the UYRB to changes in streamflow (Table 3). Generally, the contributions of human activities and variations in precipitation are, on the whole, consistent with the results from Budyko's curve, summarized in Table 2. Human activities played a dominant role in the reduction of streamflow for both catchments. However, the DMCs and Budyko's curve methods do not agree on the specific contribution fractions at all period in two sub-catchments. The variation stage I of YRB, for example, are more affected by human activities based on the Budyko's curve methods. However, the pattern of variation stage II is reversed. This discrepancy may be due to the different factors considered by the two methods, as the DMCs equation only considers precipitation. The first variation period has lower $\mathrm{ET}_{0}$, which would cause higher climatic contributions for DMCs method ignoring the $\mathrm{ET}_{0}$ variables relatively to the results of Budyko's curve method. Mo et al. (2018) found that the abrupt change point of runoff series occurred in 1984 and human activities were responsible for $72 \%$ of the total reduction in mean annual streamflow, while the remaining $13 \%$ was attributable to climate variability in the UYRB. This observation is on the whole consistent with our results, to a certain extent. However, our results do not completely agree with Hu et al. (2016). They found that climate variability were responsible for most of the total reduction in mean annual streamflow during 1980s 1990s. The discrepancies may be due to that the influence factors considered are different, because $\mathrm{Hu}$ et al. only considered the land use/cover change, ignoring the water for human consumption.

[Table 3 here]

\subsection{Anthropogenic impacts on streamflow in the UYRB}

In 1978, the land reform policy that returned responsibility for reallocated land to farmers was enacted. Since then, farmers have assumed absolute responsibility for productively managing their own lands (Gibson, 2020). As most of the activities occurred at different socio-economic and political conditions, relating the different socio-economic periods and the associated human activity with abrupt runoff changes could be helpful in determining the main driving factors of runoff decline (Gerstengarbe and Werner, 1999). The "Capital water resources planning" was started in 2002, and it was completed in 2003. The accumulated area of soil and water loss control in the study area is $1841 \mathrm{~km}^{2}$, and the engineering measures such as fish scale pit, horizontal ditch and check dam play an important role (Tan, 2004). In addition, forest and grass measures 
have been taken, and a large number of irrigation areas have been built (Wang, 2003). According to the field survey, flood irrigation is widely used in farmland near the upper reaches of Yang River and Sanggan River, up to $600 \sim 800 \mathrm{~m}^{3} / \mathrm{mu} /$ year, which greatly reduces the river discharge. It could therefore be deduced that human activity is the main driving factor of declining runoff in the study area. Beijing, the capital of china, began to carry out systematic management of YRB since 2019, which is to restore water conservation and ecological environment support functions. This study can provide valuable conclusions for the systematic planning of YRB.

\subsection{Limitations of this study}

In this study, there's no quantitative analysis on the various factors of climate and human activities that affect runoff, which is the main content of our work in the future. In addition, the mutation point detection has a certain degree subjectivity, which needs further study.

\section{Conclusions}

This study examines the spatial distribution and temporal variation of precipitation, $\mathrm{ET}_{0}$, temperature and streamflow by using hydro-climatic series from the 1961 to 2017 in the UYRB. Impacts of climate variability and human activities were investigated using Budyko's curve, and potential causes for the streamflow changes were identified. The conclusion of our study can be summarized as follows.

A general decrease in the annual $\mathrm{ET}_{0}$ and a rising temperature trend have been detected in the UYRB. The average annual streamflow shows a significant decrease at both sub-catchments. Abrupt changes in streamflow occurred in the 1982 and 2003, which may have resulted from the implementation of land reform policy and "Capital water resources planning".

Climate variability and human activities are two distinct contributors to the observed streamflow reduction. Consistent results were obtained from the Budyko's curve equation and double mass curves, although there's a slight discrepancy between the two methods caused by $\mathrm{ET}_{0}$ variable. Generally, human activities accounted for more of the streamflow changes in the UYRB, which contributed at least $60 \%$ (or more) of the runoff decline. The adoption of the household contract responsibility system since 1982 altered the natural streamflow regimes and led to an abrupt reduction in streamflow. The overall results show that human activities, such as soil and water conservation projects, the construction of key water control projects and agricultural irrigation seem to be the major causes of the significant decline in the annual streamflow in the UYRB over the last four decades.

\section{Acknowledgements}

The work was supported by National Key Research and Dvelopment plan (No.2016YFC0401403), this work was jointly supported by the National Natural Science Foundation of China (No.41930865).

\section{REFERENCES}

Abu-Allaban, M., El-Naqa, A., Jaber, M. et al., 2015. Water scarcity impact of climate change in semi-arid regions: a case study in Mujib basin, Jordan. Arab J Geosci 8, 951-959.

Allen, R.G., Pereira, L.S., Raes, D., Smith, M., 1998. Crop evapotranspiration guidelines for computing crop water requirements. FAO Irrigation and Drainage Paper No. 56. FAO. 
Arnell, N. W., 2004. Climate change and global water resources: SRES emissions and socio-economic scenarios. Global Environmental Change, 14(1), 31-52.

Benedito B., Colin C., William J. C., Luis V. C., Peter H. G., Pavel K., Mohamed A. K., Daniel P., Loucks J. L., Sunita N., Xia J., Gulbenkian Think Tank on Water and the Future of Humanity. 2014. Water and the future of humanity.

Budyko, M.I., 1974. Climate and Life. Academic Press, New york, CA.

Nurtaev, B., 2015. Influence of climate variability on large rivers runoff. 371:211-214.

Choi, W., Rasmussen, P.F., Moore, A.R., Kim, S.J., 2009. Simulating streamflow response to climate scenarios in central Canada using a simple statistical downscaling method. Climate Res. 40 (1), 89-102.

Ding A. Z., Zhao Y. J., Hao D., Zhang S. R., Qiao G. J., 2013. Analysis of variation characteristics of runoff and their influencing factors in the yongding river basin. South-to-North Water Transfers and Water Science \& Technology. 11(64), 17-22. [in Chinese]

Donohue, R. J., M. L. Roderick, and T. R. McVicar, 2011. Assessing the differences in sensitivities of runoff to changes in climatic conditions across a large basin, J. Hydrol., 406(3-4), 234-244.

Dooge, J.C.I., Bruen, M., Parmentier, B., 1999. A simple model for estimating the sensitivity of runoff to long-term changes in precipitation without a change in vegetation. Adv. Water Resour. 23 (2), 153-163.

Emad H., Aondover T., Pierre-Emmanuel K., Race C., Yang H., 2018. Runoff sensitivity to climate change in the Nile River Basin, Journal of Hydrology, 561, 312-321.

Falcone, James A., J. C. Murphy, and L. A. Sprague, 2018. "Regional patterns of anthropogenic influences on streams and rivers in the conterminous United States, from the early 1970s to 2012." Journal of Land Use Science 13:6, 585-614.

Fohrer, N., Haverkamp, S., Frede, H., 2005. Assessment of the effects of land use patterns on hydrologic landscape functions: development of sustainable land use concepts for low mountain range areas. Hydrol. Process. 19(3), 659-672.

Fu B. On the calculation of land surface evaporation [J]. Atmospheric science, 1981, 5 (001): 25-33. [in chinese]

Gerstengarbe, F.W., Werner, P.C., 1999. Estimation of the beginning and end of recurrent events within a climate regime. Climate Research 11, 97-107.

Gibson, J., 2020. Aggregate and distributional impacts of china's household responsibility system. Australian Journal of Agricultural and Resource Economics, 64(1).

Hang, Y.F., Guan, D.X., Jin, C.J., Wang, A.Z., Wu, J.B., Yuan, F.H., 2011. Analysis of impacts of climate variability and human activity on streamflow for a river basin in northeast China. J. Hydrol. 410 (3-4), 239-247.

Hu H, Li W, Yi X, Wang H., 2016. Simulation of the possible influence of land use/cover change on the hydrological process in yongding river watershed of china. Chinese Journal of Agricultural Resources and Regional Planning, 37(3), 74-83. [in Chinese]

Huang B, Hao C, Li R, Zheng H., 2018 Research Progress on the Quantitative Methods of Calculating Contribution Rates of Climate Change and Human Activities to Surface Runoff Changes(in chinese). Journal of Natural Resources.

Huntington, T.G., 2006. Evidence for intensification of the global water cycle: review and synthesis. J. Hydrol. 319 (1-4), 83-95.

Jinbo, L., 2012. Geological background along the banks of the yongding river. Urban Geology. 
Kendall, M.G., 1975. Rank Correlation Methods. Charles Griffin, London.

Li, D., Pan, M., Cong, Z., Zhang, L., Wood, E., 2013. Vegetation control on water and energy balance within the Budyko framework. Water Resources Research, 49(2), 969-976.

Liu C., Zhan C., Xia J., Cao J., 2014. Review on the influences of climate change and human activities on runoff. Journal of Hydraulic Engineering, 45(4):379-385+393. [in chinese]

Mann, H.B., 1945. Non-parametric test against trend. Econometrika 13, 245-259.

Ma, Z., Kang, S., Zhang, L., Tong, L., Su, X., 2008. Analysis of impacts of climate variability and human activity on streamflow for a river basin in arid region of northwest China. J. Hydrol. 352 (3-4), 239-249.

Milly, P.C.D., Betancourt, J., Falkenmark, M., Hirsch, R.M., Kundzewicz, Z.W., Lettenmaier, D.P., Stouffer, R.J., 2008. Climate change - stationarity is dead: whither water management? Science 319, 573-574.

Milly, P.C.D., Dunne, K.A., 2002. Macroscale water fluxes - 2. Water and energy supply control of their interannual variability. Water Resour. Res. 38 (10), 1206.

Mo C, Ruan Y, Mo G, ZHU X, Sun G., 2018. Studying Response of Runoff to Climate Change and Human Activities Based on Elastic Coefficient(in chinese). JOURNAL OF CHINA HYDROLOGY, 38(2): 41-45.

Mu, X., Zhang, L., McVicar, T.R., Chille, B.S., Gao, P., 2007. Analysis of the impact of conservation measures on stream flow regime in catchments of the Loess Plateau, China. Hydrol. Process. 21 (16), $2124-2134$.

Novotny, E.V., Stefan, H.G., 2007. Stream flow in Minnesota: indicator of climate change. Journal of Hydrology 334, 319-333.

Pikounis, M., 2003 Application of the SWAT Model in the Pinos River Basin Under Different Land Use Cases. Global Nest Journal, 5, 71-79.

Ren, L., Wang, M., Li, C., Zhang, W., 2002. Impacts of human activity on river runoff in the northern area of china. Journal of Hydrology, 261(1), 204-217.

Searcy, J.K., Hardison, C.H., 1960. Double-mass curves. U. S. Geol. Surv. Water Supply Pap. 1541-B, $31-66$.

Tan G. Analysis on the implementation of sustainable utilization planning of water resources in the capital in the early 21st century [J]. Haihe Water Conservancy, 2004 (04): 25-26. [in chinese]

Tao, H., Gemmer, M., Bai, Y.G., Su, B.D., Mao, W.Y., 2011. Trends of streamflow in the Tarim River Basin during the past 50 years: human impact or climate change? J. Hydrol. 400 (1-2), 1-9.

Wada, Y., De Graaf I. E. M., \& Van Beek L. P. H., 2016. High-resolution modeling of human and climate impacts on global water resources. Journal of Advances in Modeling Earth Systems.

Wang, D. Analysis on the progress and measures of implementing the capital water resources planning project in Zhangjiakou. Haihe Water Conservancy, 2003 (05): 12-13. [in chinese]

Wang, G., Zhang, J., Liu, J., et al., 2011. The sensitivity of runoff to climate change in different climatic regions in China. Advances in Water science, 22(3):307-314.

Wang, L., 2004. Distributed Hydrological Modeling of the Yongding River Basin and Surface Water Resources Assessment, M.S. thesis, Tsinghua University, Beijing. [In Chinese].

Wang, L., Wang, Z., Koike, T., Yin, H., Yang, D., \& He, S., 2010. The assessment of surface water resources for the semi-arid yongding river basin from 1956 to 2000 and the impact of land use change. Hydrological Processes, 24(9):1123-1132. 
Wang, Y., Ding, Y.J., Ye, B.S., Liu, F.J., Wang, J., 2013a. Contributions of climate and human activities to changes in runoff of the Yellow and Yangtze rivers from 1950 to 2008. Sci. China: Earth Sci. 56, 1398-1412.

Xia, J., 2002. A Perspective on Hydrological Base of Water Security Problem and Its Application Study in North China. PROGRESS IN GEOGRAPHY, 21(6): 517-526. [In Chinese]

Xia, J., Liu, M., Jia, S., Song, X., Luo, Y., \& Zhang, S., 2004. Water security problem and research perspective in north china. Journal of Natural Resources, 19(5): 550-560. [In Chinese]

Xia, J., Zeng, S., 2012. Hydrological Responses to Climate Change in the Water Receiving Area of the Middle Route Project for South-to-North Water Transfer[J]. Bulletin of the Chinese Academy of Sciences, 2012(01):19-33.

Xia, J., Zeng, S., Du, H., et al., 2014. Quantifying the effects of climate change and human activities on runoff in the water source area of Beijing, China. Hydrological Sciences Journal, 59(10):1794-1807.

$\mathrm{Xu} \mathrm{X}$. Hydrological response of typical watershed under climate change [phd thesis]. Tsinghua University, 2012. [in chinese]

Yang, H. B., D. W. Yang, Z. D. Lei, and F. B. Sun (2008b), New analytical derivation of the mean annual water-energy balance equation, Water Resour. Res., 44(3), W03410.

Yang, Y., Tian, F., 2009. Abrupt change of runoff and its major driving factors in haihe river catchment, china. Journal of Hydrology, 374(3-4), 373-383.

Yao, W.Y., Xu, J.H., Ran, D.C., 2011. Assessment of changing trends in streamflow and sediment fluxes in the Yellow River basin. 324. Yellow River Conservancy Press,Zhengzhou.

Yue, S., Wang, C.Y., 2004. The Mann-Kendall test modified by effective sample size to detect trend in serially correlated hydrological series. Water Resour. Manage 18 (3), 201-218.

Zeng, S., Zhang, L., Xia, J., \& Yang, Z., 2013. Water cycle characteristic and its responses to climate change of the yongding river basin. Journal of Basic science and Engineering, 21(3), 501-511.

Zhai, J.Q., Su, B.D., Krysanova, V., Vetter, T., Gao, C., Jiang, T., 2010. Spatial variation and trends in PDSI and SPI indices and their relation to streamflow in ten large regions of China. J. Clim. 23 (3), 649-663.

Zhang, L., Chen, X., Zhao, Z., Hu, Z., 2008. Progress in Study of Climate Change Impacts on Hydrology and Water Resources. Progress in Geography, 27(3), 60-67. [In Chinese].

Zhang, L., Dawes, W., \& Walker, G., 2001. Response of mean annual evapotranspiration to vegetation changes at catchment scale. Water Resources Research, 37(3), 701-708.

Zhang, L., Hickel, K., Dawes, W.R., Chiew, F.H.S., Western, A.W., Briggs, P.R., 2004. A rational function approach for estimating mean annual evapotranspiration. Water Resour. Res. 40 (2), W02502.

Zhang, L., Yu, S., Duan, Y., Shan, L., Chen, X., Xu, Z., 2013. Quantitative assessment of the effects of climate change and human activities on runoff in the yongding river basin. Progressus Inquisitiones De Mutatione Climatis, 9 (6), 391-397.

Zhang, S., Lu, X., 2009. Hydrological responses to precipitation variation and diverse human activities in a mountainous tributary of the lower Xijiang, China. Catena 77 (2), 130-142.

Zhang, X.P., Zhang, L., Zhao, J., Rustomji, P., Hairsine, P., 2008. Responses of streamflow to changes in climate and land use/cover in the Loess Plateau. Water Resources Research, China, 44.

Zhang, Y., Guan, D., Jin, C., Wang, A., Wu, J., Yuan, F., 2011. Analysis of impacts of climate variability and human activity on streamflow for a river basin in northeast China. J. Hydrol. 410 (3-4), 239-247. 
Zhao, G., Tian, P., Mu, X., Jiao, J., Wang, F., \& Gao, P., 2014. Quantifying the impact of climate variability and human activities on streamflow in the middle reaches of the yellow river basin, china. Journal of Hydrology, 519, 387-398.

Zhou, G., Wei, X., Chen, X., Zhou, P., Liu, X., Xiao, Y., ... Su, Y., 2015. Global pattern for the effect of climate and land cover on water yield.Nature Communications, 6.
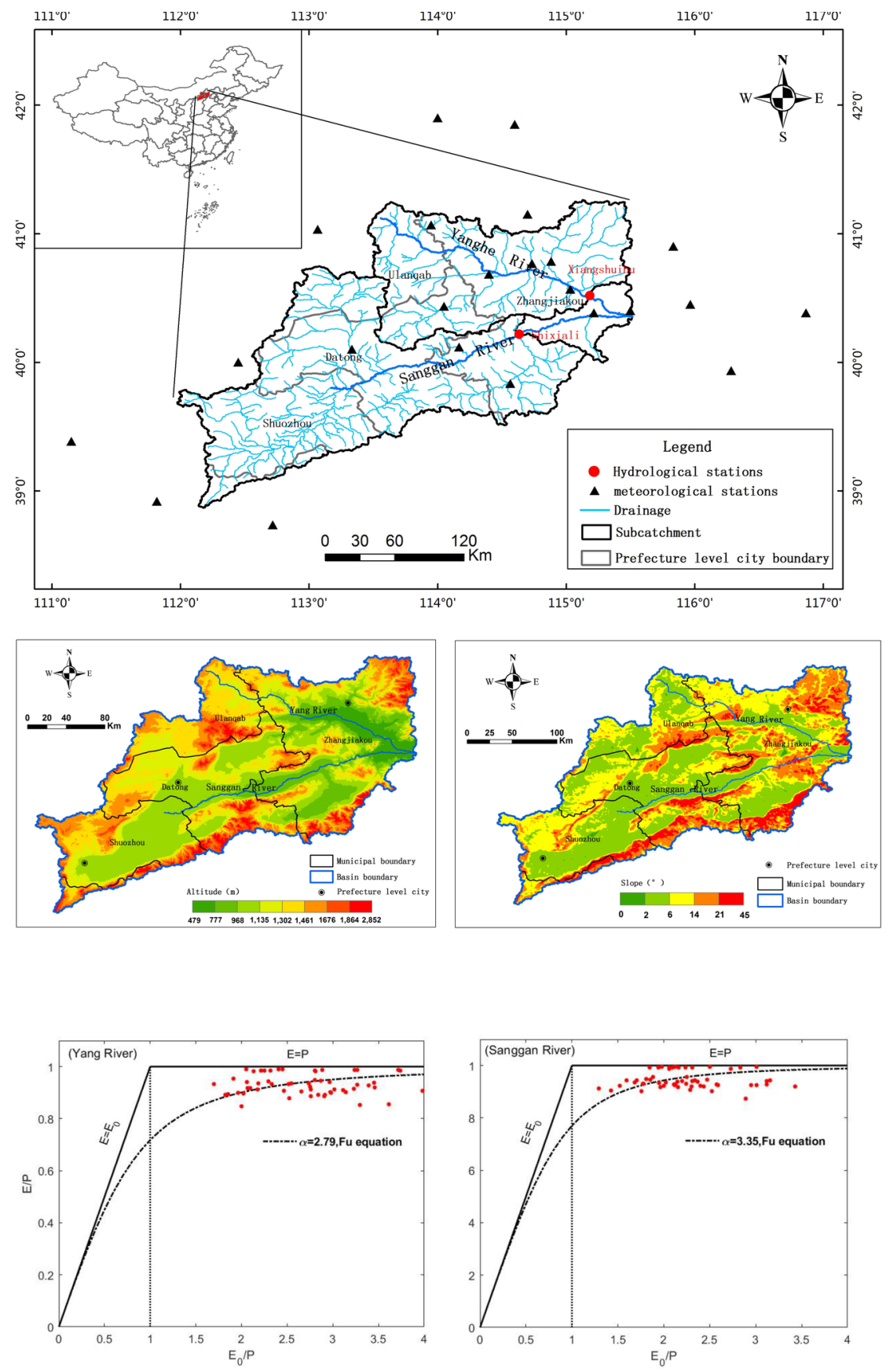

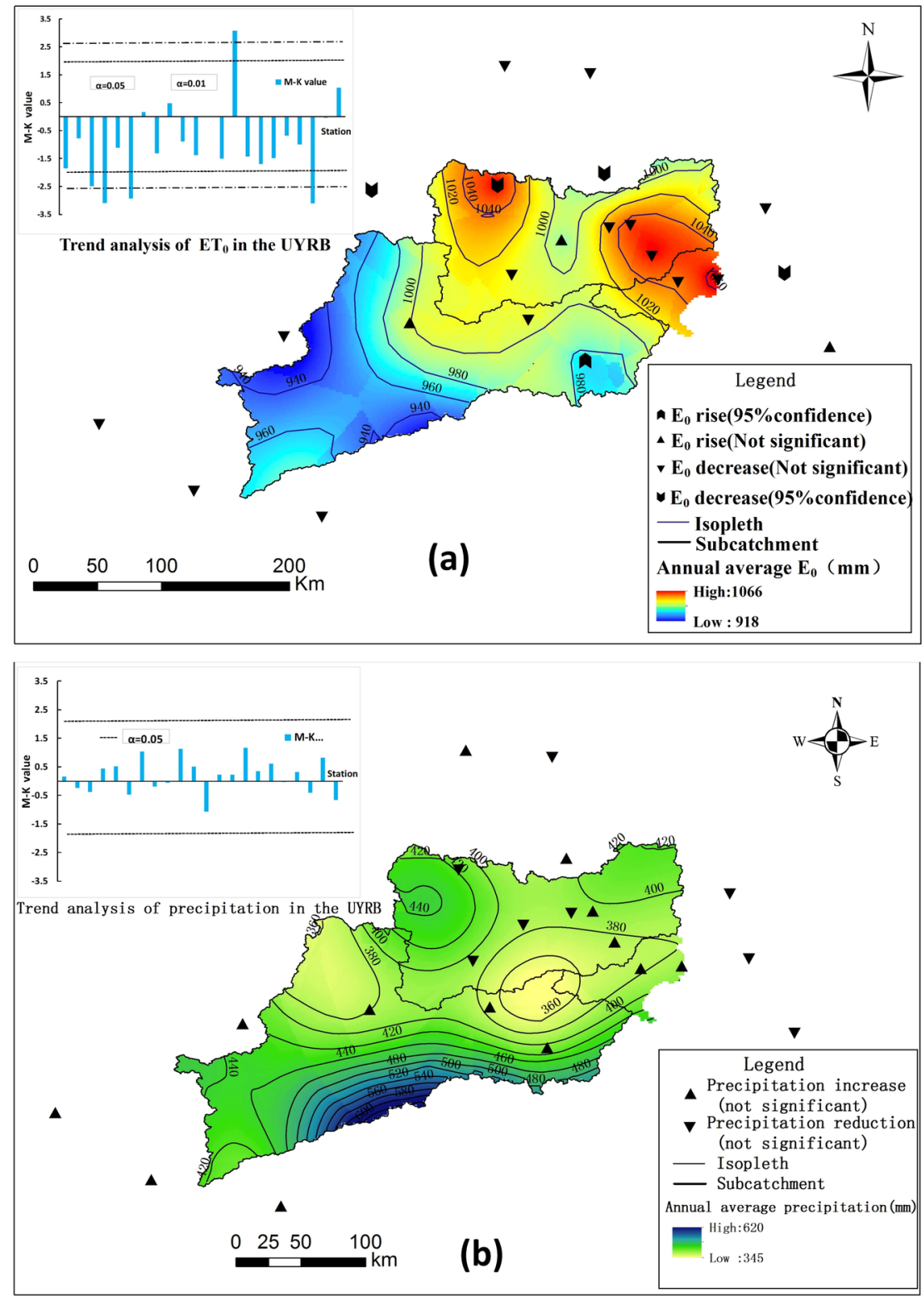

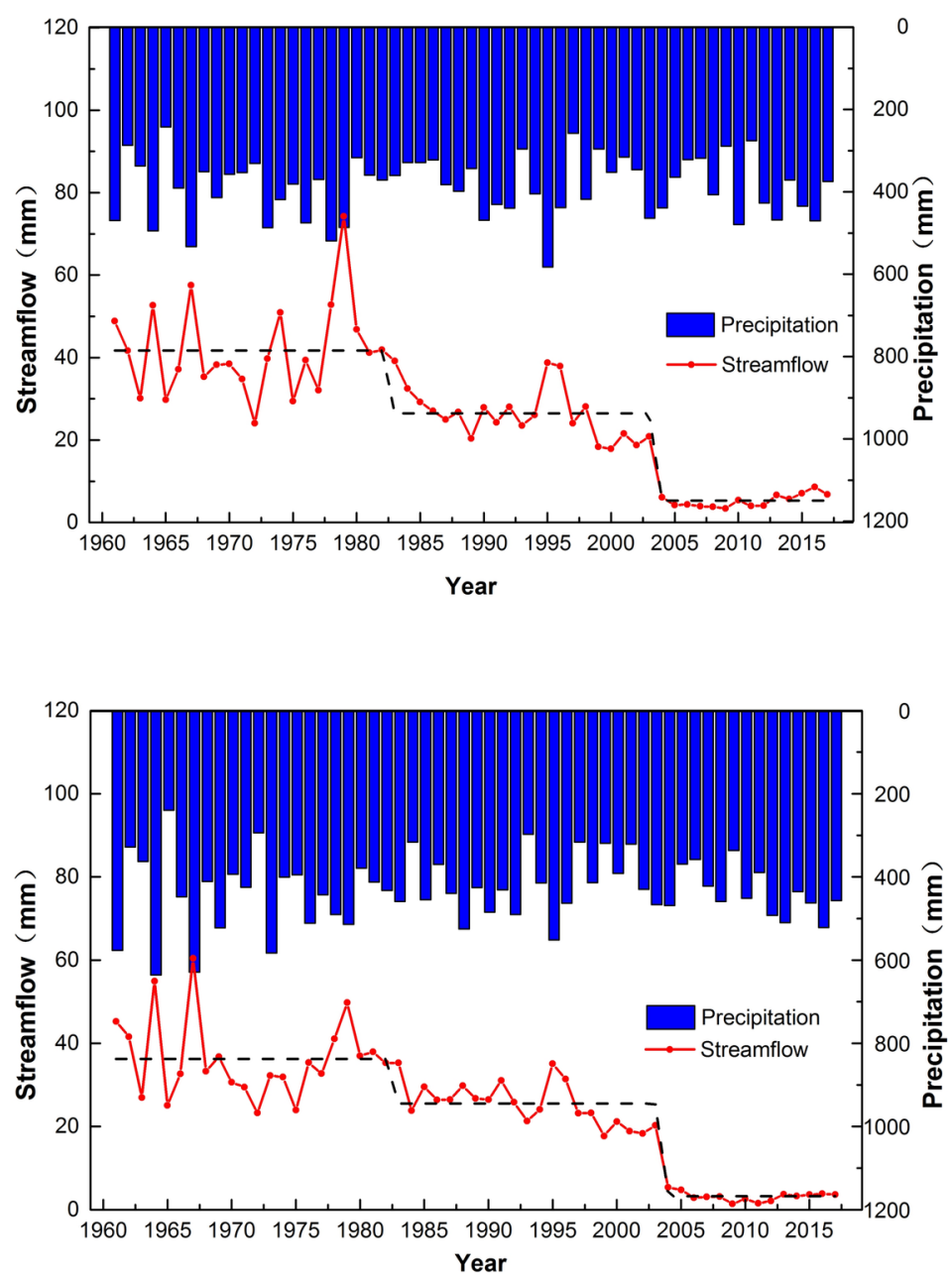

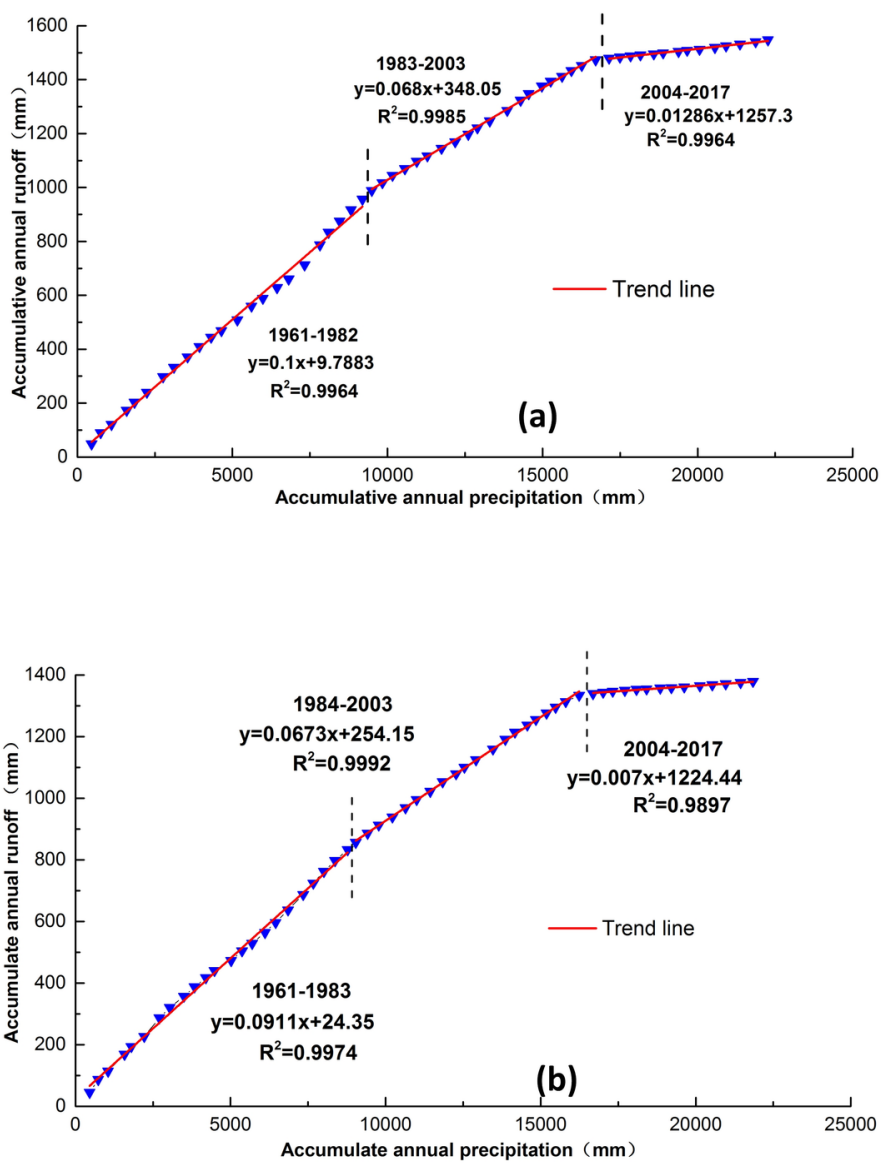

\section{Hosted file}

table1.pdf available at https://authorea.com/users/360949/articles/482477-impacts-ofclimate-change-and-human-activities-on-streamflow-in-the-upper-basin-of-the-yongdingriver-north-china

\section{Hosted file}

table2.pdf available at https://authorea.com/users/360949/articles/482477-impacts-ofclimate-change-and-human-activities-on-streamflow-in-the-upper-basin-of-the-yongdingriver-north-china

\section{Hosted file}

table3.pdf available at https://authorea.com/users/360949/articles/482477-impacts-ofclimate-change-and-human-activities-on-streamflow-in-the-upper-basin-of-the-yongdingriver-north-china 